\title{
Retrofit of Thin-walled Steel Tanks for Low Liquid Level Operation
}

Link to publication record in Manchester Research Explorer

\section{Citation for published version (APA):}

Maraveas, C., \& Miamis, K. (2013). Retrofit of Thin-walled Steel Tanks for Low Liquid Level Operation. In 10th Pacific Structural Steel Conference (PSSC 2013) (pp. 1132-1137)

\section{Published in:}

10th Pacific Structural Steel Conference (PSSC 2013)

\section{Citing this paper}

Please note that where the full-text provided on Manchester Research Explorer is the Author Accepted Manuscript or Proof version this may differ from the final Published version. If citing, it is advised that you check and use the publisher's definitive version.

\section{General rights}

Copyright and moral rights for the publications made accessible in the Research Explorer are retained by the authors and/or other copyright owners and it is a condition of accessing publications that users recognise and abide by the legal requirements associated with these rights.

\section{Takedown policy}

If you believe that this document breaches copyright please refer to the University of Manchester's Takedown Procedures [http://man.ac.uk/04Y6Bo] or contact uml.scholarlycommunications@manchester.ac.uk providing relevant details, so we can investigate your claim.

\section{OPEN ACCESS}




\title{
Retrofit of Thin-walled Steel Tanks for Low Liquid Level Operation
}

\author{
C. Maraveas; K. Miamis \\ Department of Structural Engineering \\ C. MARAVEAS PARTNERSHIP-Consulting Engineers, Athens, Greece \\ c.maraveas@maraveas.gr; steelstru@maraveas.gr
}

\begin{abstract}
The safe operation of steel oil storage tanks is vital for the petroleum industry. Such tanks are typically thin-walled, cylindrical, with large diameters and are not mechanically anchored to the foundation. Until recently, code provisions were oriented towards the design of tanks operating at high levels of the contained liquid and emphasis was given on preventing failure modes associated with yielding of the shell (plastic limit state). Based on this concept, the majority of the existing tanks were constructed with variable shell thickness, because tensile stresses (which result majorly from hydrostatic pressure) reduce towards the top of the tank. To account for structural stability issues of the very thin upper shell courses, stiffening rings were commonly placed on their circumference. However, the stiffening arrangements of existing tanks might not be sufficient to prevent buckling of the shell when these operate at low liquid levels. Therefore, the safety of such structures has to be reevaluated. In this paper, retrofit scenarios for two representative, large-scale oil storage tanks (with diameters of approximately $88 \mathrm{~m}$ and $47 \mathrm{~m}$ ) operating at low liquid level are proposed in order for the provisions of the Eurocodes to be satisfied. For the larger tank, which is open-top, two additional ring stiffeners were necessary to increase (by reduction of the buckling length) the circumferential buckling resistance of the higher tiers, which was critical in meeting the requirements set by the Eurocodes. The retrofit proposal for the other tank (which supports a conical roof) included the attachment of vertical stiffeners to account for the high meridional stresses developed in the thinner courses. Moreover, the attachment of three stiffening rings was suggested to further reduce the effect of comprehensive hoop stresses on shell buckling. Cost data regarding the proposed retrofit scenarios are presented. Helpful conclusions regarding the strengthening of such structures and the efficiency of the Eurocodes are drawn.
\end{abstract}

\section{Introduction}

Large diameter, thin-walled steel tanks are the most common selection for oil storage purposes. Their extensive use in the petroleum industry during the last decades led to the publication of relevant design specifications, the most common of which is the American standard API 650 (2007). Despite this, evaluation of shell buckling, which becomes a critical design consideration when tanks are filled at low liquid levels, is not adequately addressed in current design specifications, with the exception of the European standard EN1993-1-6 (2007). The scientific, state-of-the-art methodologies proposed by this code have already been highlighted in other work by the authors (Maraveas and Miamis, 2013a). This article presents the retrofit proposal for two existing large diameter steel tanks which did not meet the buckling requirements of EN1993-1-6 (2007) when operating at low levels of the contained liquid. 


\section{Description of the Existing Tanks}

The two cylindrical, large diameter steel tanks discussed in this article are used for oil storage in the refinery of Motor Oil Hellas S.A., which is located in the region of Korinthos, Greece. These flat-bottom, self-supported tanks are not anchored to their foundation. Tank T-761 is open-top, while a conical steel roof (with a slope of 1/6) is attached to the top of tank T-776. The geometry of the tanks and the contained liquid level considered in their structural safety evaluation is given in Table 1. Both tanks have thin-walled shells with stepwise variable thickness and ring stiffeners placed at distinct locations. Relevant information for the shell courses is provided in Table 2. Pictures of the tanks (before retrofit) are presented in Figure 1.

Table 1: Geometrical characteristics of tanks T-761 and T-776 before retrofit

\begin{tabular}{|c|c|c|c|c|c|c|}
\hline $\begin{array}{c}\text { Tank } \\
\text { ID }\end{array}$ & $\begin{array}{c}\text { Shell } \\
\text { Height } \\
(\mathrm{m})\end{array}$ & $\begin{array}{c}\text { Roof } \\
\text { Height } \\
(\mathrm{m})\end{array}$ & $\begin{array}{c}\text { Inside } \\
\text { Diameter } \\
(\mathrm{m})\end{array}$ & $\begin{array}{c}\text { Location of } 1^{\text {st }} \\
\text { Stiffening Ring } \\
(\mathrm{m})\end{array}$ & $\begin{array}{c}\text { Location of } 2^{\text {nd }} \\
\text { Stiffening Ring } \\
(\mathrm{m})\end{array}$ & $\begin{array}{c}\text { Liquid } \\
\text { Level } \\
(\mathrm{m})\end{array}$ \\
\hline T-761 & 19.500 & - & 88.430 & 15.350 & 18.400 & 0.5 \\
\hline T-776 & 20.032 & 3.911 & 46.939 & 14.860 & - & 1.0 \\
\hline
\end{tabular}

Table 2: Shell course information for tanks T-761 and T-776 before retrofit

\begin{tabular}{|c|c|c|c|c|c|c|}
\hline \multirow{2}{*}{ Course ID } & \multicolumn{2}{|c|}{$\begin{array}{c}\text { Width of } \\
\text { Course }(\mathrm{mm})\end{array}$} & \multicolumn{2}{c|}{$\begin{array}{c}\text { Thickness of } \\
\text { Course (mm) }\end{array}$} & \multicolumn{2}{c|}{$\begin{array}{c}\text { Minimum specified } \\
\text { Yield stress (MPa) }\end{array}$} \\
\cline { 2 - 7 } & Tank T-761 & Tank T-776 & Tank T-761 & Tank T-776 & Tank T-761 & Tank T-776 \\
\hline 1 & 2222 & 2438 & 38.60 & 22.25 & 345 & 345 \\
\hline 2 & 2222 & 2438 & 37.18 & 18.93 & 345 & 345 \\
\hline 3 & 2222 & 2438 & 28.20 & 16.24 & 345 & 345 \\
\hline 4 & 2222 & 2438 & 24.59 & 13.57 & 345 & 345 \\
\hline 5 & 2222 & 2438 & 19.96 & 10.9 & 345 & 345 \\
\hline 6 & 2222 & 1940 & 15.60 & 8.22 & 345 & 345 \\
\hline 7 & 2222 & 1940 & 11.20 & 8.00 & 345 & 275 \\
\hline 8 & 2222 & 1940 & 9.50 & 8.00 & 245 & 275 \\
\hline 9 -top & 1724 & 1940 & 9.50 & 8.00 & 245 & 275 \\
\hline
\end{tabular}

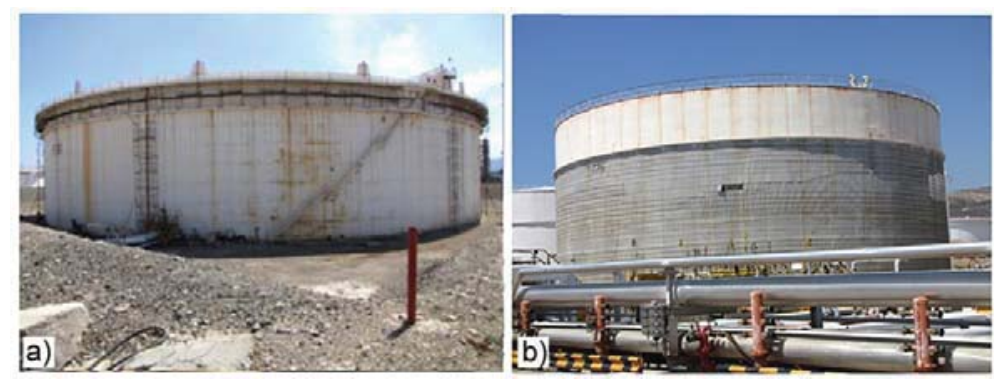

Figure 1: Photographic material for tank T-761 (left) and tank T-776 (right)

\section{Simulation and Analysis of the Existing Tanks}

In order for the tanks to safely operate at low liquid level, the owner requested that the requirements of the Eurocodes, which have normative effect in Greece, be satisfied. Calculations showed that the critical limit state was buckling of the shell, which was checked according to EN1993-1-6 (2007). This standard provides a wide range of analysis methods 
for shell buckling evaluation. The "stress design" approach, in which buckling resistance is expressed in terms of stresses that are compared with shell analysis stresses, was deemed the most appropriate. The tanks were simulated according to the principles of the Finite Element Method (FEM), using the commercial software STAAD.Pro V8i (2007). All relevant loads specified in the Eurocodes were applied. Plate elements, which incorporate membrane and bending action, were used to simulate the shell, bottom and roof (if any) of the tanks. Stiffeners, roof trusses e.t.c. were modeled by beam elements. The generation of the FE mesh accounted for shell thickness variation and stiffener location. Detailed discussion of the FE models and analysis results are given elsewhere (Maraveas and Miamis, 2013a).

\section{Retrofit of the Tanks}

The analysis of the existing tanks showed that the shell buckling requirements set by EN1993-1-6 (2007) are not met (Maraveas and Miamis, 2013a, 2013b). As a result, the owner requested the strengthening of the tanks. Based on the calculated stresses, a retrofit scenario for each tank was proposed. Moreover, according to appropriate measurements, the fabrication quality tolerance class (EN1993-1-6, 2007) for both tanks was "Class A".

\subsection{Strengthening of Tank T-761}

FEM analysis of tank T-761 showed that the buckling resistance of the shell was exceeded due to development of high circumferential (hoop) stresses due to wind action. These developed in the higher tiers (above the $5^{\text {th }}$ ), which have smaller thickness compared with the bottom ones. The meridional stresses were low (less than 5MPa) and their effect on shell buckling is not major. Based on these observations, it was deemed necessary to increase the circumferential buckling resistance $\sigma_{\theta, \text { Rd }}$ by reducing the buckling length. For this purpose, attaching two additional ring stiffeners (at elevations of $+13.15 \mathrm{~m}$ and $+16.85 \mathrm{~m}$ ) to the shell was proposed. A schematic of the retrofit scenario is shown in Figure 2.

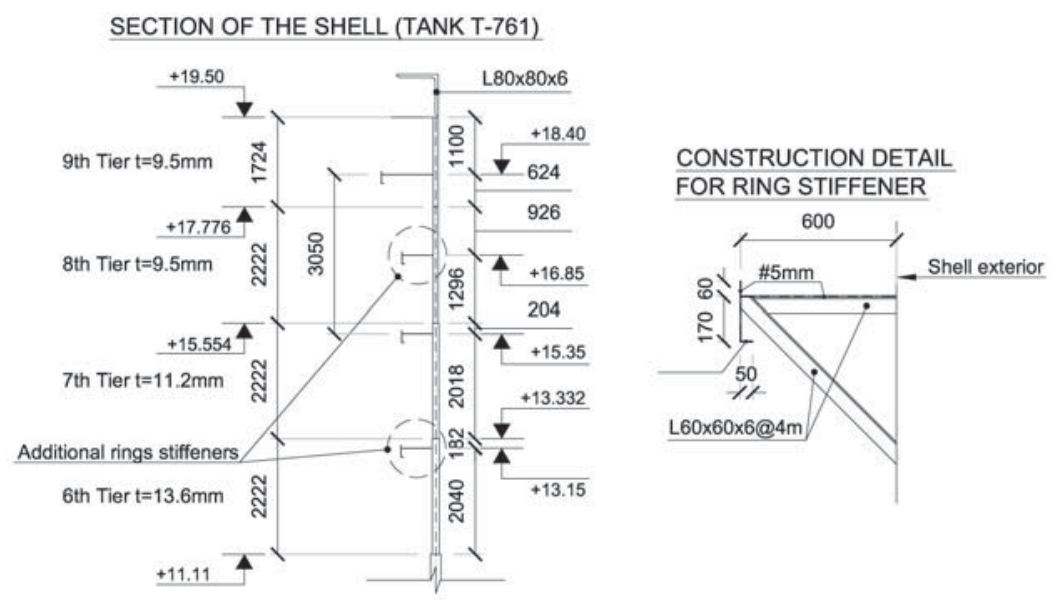

Figure 2: Retrofit scenario for tank T-761

Following the simulation procedure described in section 3, analysis of the retrofitted tank was conducted. The additional ring stiffeners were incorporated by the use of beam elements. The FEM models for the initial and the retrofitted tank are presented in Figure 3. Application of the loads and their combinations was identical for both analysis cases. 

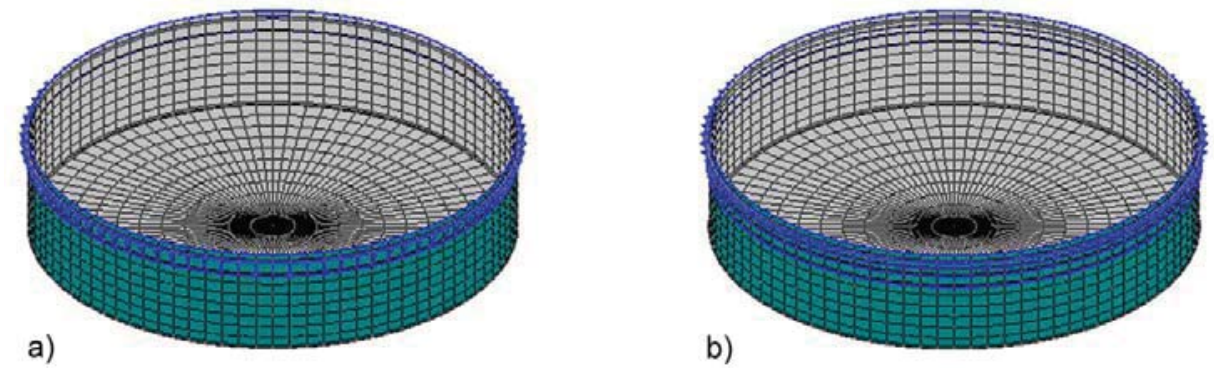

Figure 3: FE models for tank T-761 (a) before and (b) after retrofit

Results for the existing and the retrofitted tank, in terms of middle shell course stresses, are given in Table 3. Tensile stresses are denoted as " 0.00 ". The presented stresses result in the lowest safety factor for each course. Stresses remained almost identical at the lower portion of the shell, but increased (even up to 50\%) in the highest tiers due to the proposed stiffening. The location of the stiffeners was selected to optimize the buckling resistance of the shell, by maximizing the safety factors in the courses. Table 3 also presents the calculated buckling safety factors for the initial and the retrofitted shell. Placing only one stiffening ring was not sufficient to satisfy the buckling check according to EN1993-1-6 (2007). The estimated cost for the proposed strengthening is $60,000 €$ and its weight is approximately 20 tons.

Table 3: Comparison of analysis results for the existing / retrofitted tank T-761

\begin{tabular}{|c|c|c|c|c|c|c|c|c|}
\hline & \multicolumn{6}{|c|}{ Shell Stresses (MPa) } & \multicolumn{2}{|c|}{ Safety Factor } \\
\hline \multirow{2}{*}{$\begin{array}{c}\text { Course } \\
\text { ID }\end{array}$} & \multicolumn{3}{|c|}{ Existing Tank } & \multicolumn{3}{|c|}{ Retrofitted Tank } & \multirow{2}{*}{$\begin{array}{c}\text { Existing } \\
\text { Tank }\end{array}$} & \multirow{2}{*}{$\begin{array}{l}\text { Retrofitted } \\
\text { Tank }\end{array}$} \\
\hline & $\sigma_{\mathrm{x}, \mathrm{Ed}}$ & $\sigma_{\theta, \mathrm{Ed}}$ & $\tau_{\mathrm{x} \theta, \mathrm{Ed}}$ & $\sigma_{x, \text { Ed }}$ & $\sigma_{\theta, \mathrm{Ed}}$ & $\tau_{\mathrm{x} \theta, \mathrm{Ed}}$ & & \\
\hline 1 & 2.86 & 2.27 & 1.82 & 2.90 & 2.18 & 1.06 & 1.10 & 2.86 \\
\hline 2 & 0.00 & 5.48 & 0.70 & 0.00 & 5.48 & 0.67 & 0.49 & 1.19 \\
\hline 3 & 0.00 & 5.05 & 0.71 & 0.00 & 5.07 & 0.65 & 0.78 & 1.85 \\
\hline 4 & 0.63 & 6.18 & 0.57 & 0.53 & 6.17 & 0.46 & 0.70 & 1.69 \\
\hline 5 & 0.90 & 7.51 & 0.36 & 0.63 & 7.67 & 0.20 & 0.68 & 1.64 \\
\hline 6 & 1.79 & 10.10 & 0.05 & 0.78 & 9.31 & 0.33 & 0.61 & 1.43 \\
\hline 7 & 3.84 & 0.00 & 1.82 & 1.14 & 12.8 & 0.18 & 1.01 & 1.41 \\
\hline 8 & 1.66 & 9.75 & 0.53 & 1.54 & 14.7 & 0.19 & 0.60 & 1.08 \\
\hline 9 & 0.30 & 6.78 & 0.26 & 0.32 & 9.01 & 0.24 & 1.23 & 4.00 \\
\hline
\end{tabular}

\subsection{Strengthening of Tank T-776}

Contrary to tank T-761, meridional stresses in the shell of tank T-776 were large (having values as high as 8 to $9 \mathrm{MPa}$ in the thinner courses) due the self-weight of the roof and played a crucial role in determining the stability of the shell. Moreover, the circumferential stresses in the higher tiers were not negligible (ranging from 6 to $8 \mathrm{MPa}$ ). Therefore, the proposed retrofit scenario had to account for the effect of both stress components on shell buckling. To limit the effect of the hoop stresses, three additional stiffening rings, welded at the $5^{\text {th }}, 6^{\text {th }}$ and $8^{\text {th }}$ tier, were required. However, this modification was not sufficient to increase the meridional design resistance of the shell. In EN1993-1-6 (2007), the critical meridional buckling stress (which determines the axial buckling resistance) is given from Eq. (1):

$$
\sigma_{x, R c r}=0.605 E C_{x}(t / r)
$$

where $\mathrm{E}$ is the elastic modulus for steel, $\mathrm{C}_{\mathrm{x}}$ is a non-dimensionless factor, $\mathrm{t}$ is the thickness of the shell and $r$ its radius. For "medium-length" cylinders, $C_{x}=1$ (EN1993-1-6, 2007). Despite 
reducing the buckling length due to the attachment of ring stiffeners, all cylinders were still characterized as "medium-length" and, consequently, the meridional buckling strength was not modified. In order to improve it, the thickness of the shell had to be increased. This was achieved indirectly, by proposing the attachment of vertical stiffeners on tiers 6 to 8 at a radial spacing of $2.1 \mathrm{~m}$. For stiffeners spaced at distance less than 5(rt) ${ }^{1 / 2}$, EN1993-4-2 (2007) allows the shell to be treated as corrugated sheeting and refers to EN1993-4-1 (2007) for determining its equivalent orthotropic properties. After determining a fictitious sinusoidal corrugated sheet with cross-sectional properties (area, moment of inertia etc) equal to those of the stiffened shell, the equivalent thickness $t_{\mathrm{eq}}$ for smeared membrane forces parallel to the corrugations was calculated according to Eq. (2), which is given in EN1993-4-1 (2007):

$$
t_{e q}=t\left(1+\pi^{2} d^{2} / 4 l^{2}\right)
$$

where $d$ is the crest to crest distance, $t$ the thickness and 1 the wavelength of the corrugation. This equivalent thickness (calculated to be $10.5 \mathrm{~mm}$ ) was used in buckling length calculations for the vertically stiffened portion of the shell. The retrofitting scenario is given in Figure 4.
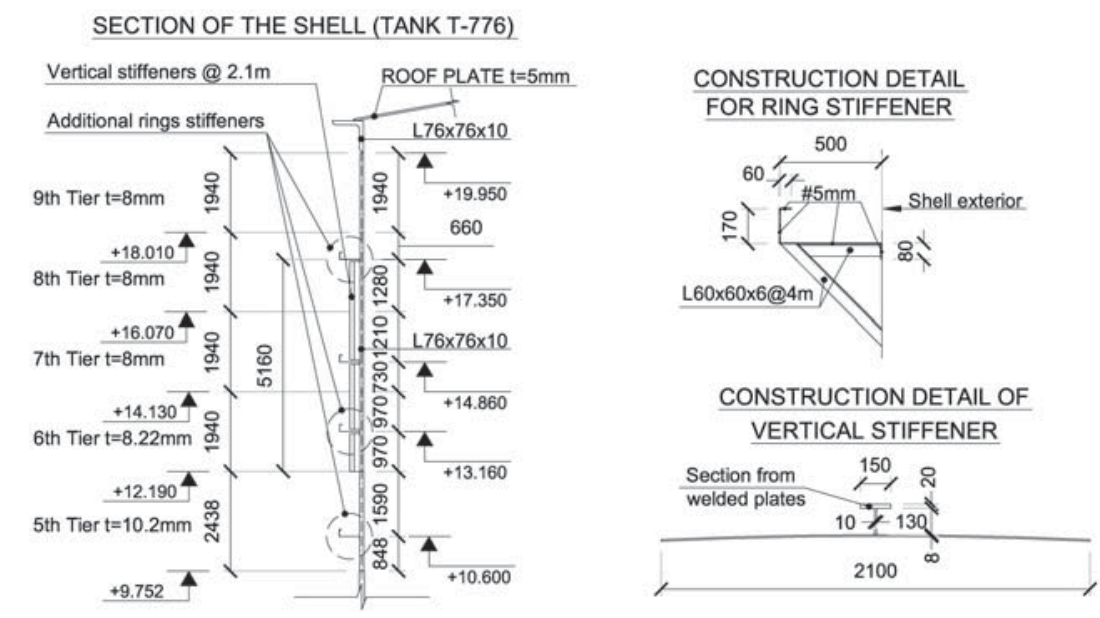

Figure 4: Retrofit scenario for $\operatorname{tank}$ T-776

To analyze the retrofitted tank, a FE model was created by appropriate modifications (mesh refinement, addition of stiffeners etc) of the initial simulation (Figure 5). The shell stresses (corresponding to the lowest safety factor) for the initial and the retrofitted tank are given in Table 4. As expected, the addition of vertical stiffeners reduced the axial compression in the shell. Even so, observation of the relevant safety factors shows that buckling requirements are marginally satisfied. The retrofit scenario will cost $65,000 €$ and weighs 25 tons.

a)

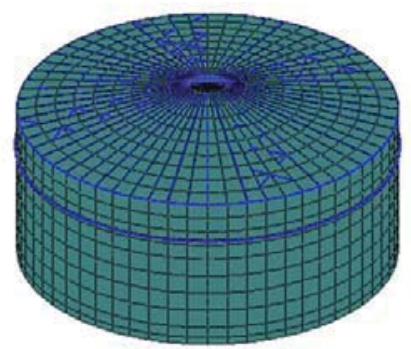

b)

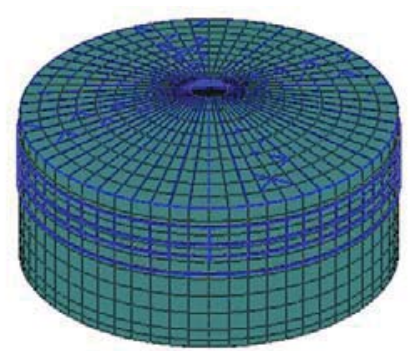

Figure 5: FEM models for tank T-776 (a) before and (b) after retrofit 
Table 4: Comparison of analysis results for the existing / retrofitted tank T-776

\begin{tabular}{|c|c|c|c|c|c|c|c|c|}
\hline & \multicolumn{5}{|c|}{ Shell Stresses $(\mathrm{MPa})$} & \multicolumn{2}{c|}{ Safety Factor } \\
\hline \multirow{2}{*}{$\begin{array}{c}\text { Course } \\
\text { ID }\end{array}$} & \multicolumn{3}{|c|}{ Existing Tank } & \multicolumn{2}{c|}{ Retrofitted Tank } & \multirow{2}{*}{$\begin{array}{c}\text { Existing } \\
\text { Tank }\end{array}$} & $\begin{array}{c}\text { Retrofitted } \\
\text { Tank }\end{array}$ \\
\cline { 2 - 8 } & $\sigma_{\mathrm{x}, \mathrm{Ed}}$ & $\sigma_{\theta, \mathrm{Ed}}$ & $\tau_{\mathrm{x} \theta, \mathrm{Ed}}$ & $\sigma_{\mathrm{x}, \mathrm{Ed}}$ & $\sigma_{\theta, \mathrm{Ed}}$ & $\tau_{\mathrm{x} \theta, \mathrm{Ed}}$ & 0.36 & 1.02 \\
\hline 1 & 1.95 & 4.36 & 1.04 & 2.01 & 4.40 & 0.92 & 0.36 & 1.72 \\
\hline 2 & 3.64 & 3.05 & 0.91 & 3.49 & 3.06 & 0.76 & 0.67 & 1.12 \\
\hline 3 & 5.48 & 4.36 & 0.65 & 4.96 & 4.73 & 0.36 & 0.50 & 1.25 \\
\hline 4 & 7.12 & 5.13 & 0.21 & 6.03 & 4.03 & 0.25 & 0.46 & 1.19 \\
\hline 5 & 8.40 & 6.07 & 0.56 & 6.55 & 4.63 & 0.05 & 0.41 & 1.02 \\
\hline 6 & 9.16 & 7.51 & 1.80 & 7.18 & 6.39 & 0.52 & 0.32 & 1.01 \\
\hline 7 & 6.71 & 7.55 & 0.17 & 5.44 & 5.77 & 0.66 & 0.55 & 1.06 \\
\hline 8 & 5.10 & 6.60 & 1.09 & 4.21 & 8.92 & 0.94 & 0.39 & 1.47 \\
\hline $9-$ top & 1.30 & 4.30 & 0.13 & 3.85 & 1.96 & 0.01 & 0.98 & \\
\hline
\end{tabular}

\section{Conclusions}

This article presented the retrofit of two thin-walled, large diameter steel tanks located in Greece. Stiffening of their shell at discrete locations was proposed to meet the requirements of the Eurocodes. The retrofit scenarios accounted for constructability issues and satisfied cost-related criteria set by the owner. Based on the suggested structural modifications, it can be concluded that strengthening of the shell with stiffening rings might not be sufficient when severe axial compression stresses are present (e.g. in tanks that support roofs). If this is the case, attachment of vertical stiffeners is the most efficient solution for increasing its buckling resistance. However, it should be noted that the Eurocodes propose stringent requirements regarding shell stability and clearly do not allow the use of very thin shell courses, contrary to other, earlier codes (according to which the presented tanks were designed).

\section{6. $\quad$ References}

American Petroleum Institute. (2007). Welded Tanks for Oil Storage, API Standard 650, $11^{\text {th }}$ Edition, U.S.A.

Bentley Systems, Incorporated. (2007). STAAD.Pro V8i Structural Analysis and Design Software, U.S.A.

CEN, the European Committee for Standardization. (2007). Eurocode 3 - Design of steel structures - Part 1-6: Strength and Stability of Shell Structures, European Standard EN 1993-1-6, Belgium.

CEN, the European Committee for Standardization. (2007). Eurocode 3 - Design of steel structures - Part 4-1: Silos, European Standard EN 1993-4-1, Belgium.

CEN, the European Committee for Standardization. (2007). Eurocode 3 - Design of steel structures - Part 4-2: Tanks, European Standard EN 1993-4-2, Belgium.

Maraveas C and Miamis K. (2013a). Shell buckling evaluation of thin-wallet steel tanks filled at low liquid level according to current design codes, In Proceedings of Annual Stability Conference. April 16-20, 2013, U.S.A. 15 pages.

Maraveas C and Miamis K. (2013b). Structural appraisal of two steel tanks filled at low liquid level according to current codes, In Proceedings of 5th International Conference on Design, Fabrication and Economy of Metal Structures. April 24-26, 2013, Hungary. pp. 211-216. 